\title{
Gebruik van medische gegevens en van lichaamsmateriaal voor wetenschappelijk onderzoek; van 'nee, tenzij'naar 'ja, mits'
}

Citation for published version (APA):

Sanders, H. W. A. (1992). Gebruik van medische gegevens en van lichaamsmateriaal voor wetenschappelijk onderzoek; van 'nee, tenzij'naar 'ja, mits'. Maastricht University. https://doi.org/10.26481/spe.19920612hs

Document status and date:

Published: 12/06/1992

DOI:

10.26481/spe.19920612hs

Document Version:

Publisher's PDF, also known as Version of record

Please check the document version of this publication:

- A submitted manuscript is the version of the article upon submission and before peer-review. There can be important differences between the submitted version and the official published version of record.

People interested in the research are advised to contact the author for the final version of the publication, or visit the DOI to the publisher's website.

- The final author version and the galley proof are versions of the publication after peer review.

- The final published version features the final layout of the paper including the volume, issue and page numbers.

Link to publication

\footnotetext{
General rights rights.

- You may freely distribute the URL identifying the publication in the public portal. please follow below link for the End User Agreement:

www.umlib.nl/taverne-license

Take down policy

If you believe that this document breaches copyright please contact us at:

repository@maastrichtuniversity.nl

providing details and we will investigate your claim.
}

Copyright and moral rights for the publications made accessible in the public portal are retained by the authors and/or other copyright owners and it is a condition of accessing publications that users recognise and abide by the legal requirements associated with these

- Users may download and print one copy of any publication from the public portal for the purpose of private study or research.

- You may not further distribute the material or use it for any profit-making activity or commercial gain

If the publication is distributed under the terms of Article $25 \mathrm{fa}$ of the Dutch Copyright Act, indicated by the "Taverne" license above, 
Universiteitsbibliotheek

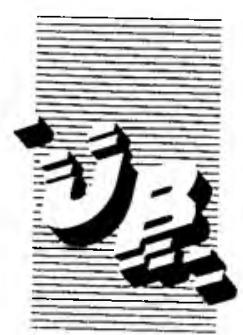

De uitleentermijn verstrijkt op:

\section{DO SET. 1992}

Rijksuniversıteil Limburg

Postbus ô 16

6200 MD Maastricht

Gelieve deze publicatie tijdig te retourneren of (telefonisch) verlenging van de uitleentermijn aan te vragen. 
Gebruik van medische gegevens en van lichaamsmateriaal voor wetenschappelijk onderzoek; van 'nee, tenzij' naar 'ja, mits'

Rede

uitgesproken bij de aanvaarding van het ambt van hoogleraar gezondheidszorgbeleid aan de Rijksuniversiteit Limburg op 12 juni 1992

door

dr mr H W A Sanders 
$0_{5} 658254$ Bibllathook L.U. Hisiburg 
Mijnheer de Rector Magnificus,

Leden van de universitaire gemeenschap,

Geachte toehoorders.

Beleid

Beleid kan betrekkelijk eenvoudig en eenduidig worden worden gedefiniëerd aan de hand van de begrippen: doel, middel en effect.

Een omschrijving van het proces van beleidsvoorbereiding, -vaststelling, -uitvoering en -evaluatie op bepaald terrein, bijvoorbeeld dat van de volksgezondheid en de gezondheidszorg, is meer complex. Men kan de volgende fasen onderscheiden:

1 Het formuleren van de doelstelling cq van subdoelen, met inachtneming van uitgangspunten, gegeven bepaalde randvoorwaarden en gelet op voorgenomen cq in gang gezet beleid op verwante gebieden;

2 Het beoordelen van in aanmerking komende middelen op effectiviteit, doelmatigheid en mogelijke bijwerkingen, en het op geleide van deze analyse selecteren en in operationele zin nader uitwerken van de meest geëigende instrumenten, methoden, werkwijzen, e.d.;

3 Het zorgdragen voor een planmatig en systematisch implementatie van de doelgerichte middelen in de praktijk, voor een registratie ten behoeve van de beoordeling van effecten, en voor procedures om, waar nodig, de uitvoering aan te passen aan opgedane ervaringen;

4 Het evalueren van het uitvoeringsproces en van de resultaten, vooral gericht op: zijn de doelstellingen bereikt, zijn de middelen op doelmatige wijze ingezet en zijn er niet verwachte neveneffecten opgetreden.

Voor het bereiken van beleidsdoelen wordt vaak verwezen en gegrepen naar het instrument van wet- en regelgeving. Deze keuze blijkt meestal gebaseerd op overspannen verwachtingen ten aanzien van het effect dat deze middelen op attitude en gedrag van groepen en individuen sorteren en op een onderschatting van de belastende gevolgen en van de kansen op niet-beoogde, niet-gewenste en soms zelfs nadelige consequenties ervan.

En verder, als tot regelgeving wordt besloten, dan is het resultaat vrijwel altijd een stelsel van verplichtingen, verboden en sancties, opgenomen in een document met gedetailleerde voorschriften van procedurele en inhoudelijke aard. Algemeen is de klacht van degenen voor wie de regels primair zijn bedoeld, dat tekst en strekking van de bepalingen, ook na lezing van de toelichtingen, onduidelijk zijn of voor meerdere uitleg vatbaar.

Alom wordt gepleit voor het terugtreden van de centrale overheid en voor decentralisatie, voor deregulering en vereenvoudiging van regelgeving, voor een bottum-up benadering bij de beleidsvoorbereiding, voor het stimuleren van zelfregulering door direct betrokken partijen en voor het voorop stellen van de eigen verantwoordelijkheid van functionele groepen en individuën.

Dat over het algemeen de afstand tussen deze voomemens en de effectuering daarvan niet sneller wordt overbrugd, kan niet aan een gemis aan activiteiten of 
het ontbreken van aanzetten in bedoelde richtingen op centraal niveau of van het maatschappelijk middenveld worden geweten. Van een negatieve opstelling van essentiële actoren is evenmin sprake. De traagheid van het proces lijkt een gevolg van de complexiteit van structuur en inrichting van onze samenleving, waarbij een verandering van een bepaald aspect belangrijke en voor een deel onvoorspelbare consequenties heeft voor andere onderdelen of voor het geheel.

Op het terrein van de geneeskunde heeft van oudsher het particulier initiatief een belangrijke rol gespeeld. Instellingen en beroepsbeoefenaren en hun organisaties hebben zich verantwoordelijk geweten voor het bereiken van een hoog peil van volksgezondheid en voor een organisatie en uitvoering van gezondheidszorg welke is aangepast aan de eisen van de tijd en de stand van de wetenschap, en gericht is op de individuele patiënt en op het bevorderen van de geneeskunde. De essentie van de verantwoordelijkheid van de overheid, zoals bedoeld in artikel 22 van de Grondwet, richt zich op (a) de kwaliteit van de zorg en de controle daarop, (b) de bereikbaarheid ervan qua functies en spreiding en in de tijd gezien en op (c) de financiële toegankelijkheid voor alle burgers. Geleidelijk aan echter heeft de overheid zjjn imvloedssfeer en taakstelling enorm uitgebreid.

Naar verwachting kan op dit, voor maatschappij en burgers zo belangrijke gebied, een snelle ombuiging/terugkeer naar méer decentraal plaatsvinden, met grotere verantwoordelijkheid voor partijen, zich uitdrukkend in een kenbaar en controleerbaar systeem van zelfordening en toetsing, zonder niet-in-te-calculeren gevolgen voor andere terreinen van overheidszorg.

Beleid is een gewichtig klinkend maar op zich inhoudsloos woord. In een correct gebruik van de term ligt de veronderstelling of de constatering besloten, dat het voor de inhoud en het resultaat van verantwoord en verantwoordelik handelen van mensen noodzakelijk is, dat denken voorafgaat aan, plaatsvindt tijdens en volgt na het doen.

Zó verstaan, is beleid op het terrein van de gezondheidszorg, de kenbaarheid ervan en het bijdragen daaraan, van groot praktisch belang. En dat niet alleen op macroniveau (landelijk; overheid, koepelorganisaties, raden en verenigingen), maar ook op meso- (universiteit, faculteit en vakgroep; onderzoekinstituut, thema en programma; ziekenhuis, afdeling en maatschap) en vooral op microniveau (individuele beroepsbeoefenaren; behandelaar, opleider en onderzoeker).

\section{Onderwerp}

Het ondeıwerp waarop ik me deze middag richt, gewenst beleid ten aanzien van het gebruik van gegevens en van lichaamsmateriaal van (potentiële) patiënten voor onderzoek dat beoogt bij te dragen aan het verkrijgen van kennis welke direct of indirect van belang is voor het bevorderen van de gezondheid of het voorkómen en bestrijden van ziekten, verdient een nadere uitteg en begrenzing.

Medische gegevens: Gegevens over de geestelijke en/of lichamelike gesteldheid van geregistreerden, verbandhoudend met diagnostiek, therapie, begeleiding en follow-up cq met beoordeling van de gezondheidstoestand, verkregen in het kader van de medische beroepsuitoefening, vastgelegd door of ten behoeve van 
de behandelend arts. Indien deze gegevens herleidbaar zijn tot een individuele natuurlijke persoon, is er sprake van medische persoonsgegevens (patiëntgegevens).

Lichaamsmateriaal: Primair voor een ander doel dan voor wetenschappelijk onderzoek, namelijk in het kader van de behandeling of beoordeling, afgenomen of verkregen menselijk materiaal (humaan restmateriaal: vocht, bloed, cellen, weefsels of organen).

Anoniem restmateriaal: voor de onderzoeker niet tot een persoon herieidbaar. Dit materiaal kan wel voorzien zijn van een code of nummer, waardoor herleiding wel door de behandelend arts mogelijk is.

Niet-anoniem restmateriaal wordt bewaard op naam of is anderszins door de onderzoeker rechtstreeks herleidbaar tot een persoon.

Wetenschappelijk onderzoek: Medisch-wetenschappelijk inclusief epidemiologisch onderzoek, zowel fundamenteel als toegepast.

Bij patiëntgebonden onderzoek zijn directe patiëntenzorg en medisch-wetenschappelijk onderzoek niet altijd te onderscheiden. Indien het doel van het onderzoek niet meer uitsluitend gericht is op de behandeling van degene van wie de gegevens of het lichaamsmateriaal afkomstig zijn, maar tevens op algemeen geldende kennisvermeerdering, is er sprake van medisch-wetenschappelijk onderzoek.

Observationeel medisch-wetenschappelijk onderzoek: analyse ten behoeve van een wetenschappelijke vraagstelling, waarvoor patiëntgegevens en/of lichaamsmateriaal nodig zijn welke in het kader van een ander doel beschikbaar zijn gekomen.

Nee, tenzij: Het individueel belang prevaleert. Voor gebruik voor een ander doel van medische persoonsgegevens en van niet-anoniem humaan restmateriaal, dat verkregen is in het kader van de medische beroepsuitoefening, is expliciete toestemming van betrokkene(n) noodzakelijk. Alleen in uitzonderingsgevallen en onder strenge en cumulatieve voorwaarden is gebruik zonder toestemming mogelijk, tenzij de betreffende patiënt tegen zodanig gebruik vooraf bezwaar heeft gemaakt.

Ja. mits: In de uitoefening van gezondheidszorg ligt naast de gerichtheid op het actuele belang van de individuele patiënt ook het bevorderen van de geneeskunst besloten. $O . a$. via het uitwisselen van medische (persoons-)gegevens, het bundelen van ervaring, het beschikbaar houden van (niet-anoniem) humaan restmateriaal en het verrichten van of bijdragen aan medisch-wetenschappelijk onderzoek. Over dit mogelijk gebruik voor een ander maar verwant doel, zowel ten behoeve van de behandeling van de betreffende patiënt in de toekomst als in het belang van de volksgezondheid/gezondheidszorg in het algemeen, dienen (potentiële) patiënten op de hoogte te zijn cq te worden geïnformeerd. Bij de verwerking van de gegevens en van het restmateriaal door derden en bij de publicatie van de resultaten dient voor niet-herleidbaarheid te worden gezorg.

In deze rede blijen buiten beschouwing:

- Het gebruik van (persoons-)gegevens van medische aard en van lichaamsmateriaal, verkregen in een andere setting, bijvoorbeeld door verzekeringsgeneeskun- 
digen, in de bedrijfsgeneeskundige zorg, ten behoeve van erfelijkheidsonderzoek, of bij bevolkingsonderzoek.

- Medische experimenten met mensen, in de zin van: proefondervindelijk wetenschappelijk onderzoek op het gebied van de geneeskunst waarvan deel uitmaakt, het onderwerpen van patiënten en andere proefpersonen aan handelingen of het opleggen aan personen van een bepaalde gedragswijze.

- Wetenschappelijk onderzoek met (pre-)embryo's en geslachtscellen.

Kort zullen aan de orde worden gesteld: relevante wettelijke bepalingen, de inhoud van adviezen van de Nationale Raad voor de Volksgezondheid en de uitwerking van een en ander in enkele privacyreglementen en codes. Daarna volgt een paragraaf beschouwingen en tot slot enkele aanbevelingen.

Van een weergave en analyse van de jurisprudentie en van de (gezondheidsrechtelijke) literatuur ter zake is, in verband met de omvang daarvan en het karakter van deze voordracht, afgezien.

\section{Regelgeving}

Met betrekking tot het onderwerp van deze voordracht zijn een aantal bepalingen van belang, vastgelegd in drie artikelen van de Grondwet, in de per 1 juli 1990 volledig in werking getreden Wet persoonsregistraties (WPR) en in het op 29-5-90 aan de Tweede Kamer aangeboden voorstel van Wet inzake de geneeskundige behandelingsovereenkomst (WGBO).

\section{Grondwet:}

- leder heeft, behoudens bij/krachtens de wet te stellen beperkingen, recht op eerbiediging van zijn persoonlijke levenssfeer. De wet stelt ter bescherming van de privacy regels met betrekking tot het vastleggen en verstrekken van persoonsgegevens. Tevens stelt de wet regels inzake de aanspraken van personen op kennisneming van over hen vastgelegde gegevens en van het gebruik dat daarvan wordt gemaakt (art 10).

- leder heeft recht op onaantastbaarheid van zijn lichaam (art 11).

- De overheid treft maatregelen ter bevordering van de volksgezondheid (art 22).

Wet persoonsregistraties ( 55 artikelen; 146 artikelleden):

- Persoonsgegevens uit een persoonsregistratie kunnen slechts worden gebruikt voor doeleinden die met het doel van de registratie verenigbaar zijn en mogen alleen worden verstrekt aan (categorieën van) personen binnen de organisatie van de houder, welke deze gezien hun taak nodig hebben (art 6).

- Voor het verstrokken van persoonsgegevens aan derden is schriftelijke toestemming van de geregistreerde vereist. Alleen ten behoeve van wetenschappelijk onderzoek of statistiek dan wel op grond van een dringende en gewichtige reden kunnen gegevens zonder toestemming aan derden worden verstrekt, voor zover de persoonlijke levenssfeer van de geregistreerden daardoor niet onevenredig wordt geschaad (art 11, leden 1 en 2). Verstrekking blift in ieder geval achterwege voor zover dit in strijd zou zijn met het beroepsgeheim (art 11, lid 3). Dit artikellid maakt feitelijke verstrekking van medische persoonsgegevens aan niet bij de behandeling betrokken derden, zonder toestemming van de geregistreerde, 
onmogelijk.

- Voor een bepaalde sector representatieve organisaties kunnen een gedragscode vaststellen met regels voor privacybescherming of aanbevelingen ten aanzien van persoonsregistraties. De Registratiekamer kan desgevraagd verklaren dat deze code in overeenstemming is met de desbetreffende wettelike bepalingen en voldoet aan redelijkerwijs aan de bescherming van de persoonlijke levenssfeer te stellen eisen (art 15).

Voorstel van Wet geneeskundige behandelingsovereenkomst (24 artikelen; 46 artikelleden):

- De hulpverlener registreert in een dossier gegevens orntrent de gezondheidstoestand van de patiënt en over de uitgevoerde verrichtingen, en neemt andere stukken met dergelijke gegevens daarin op, een en ander voor zover dit voor een goede hulpverlening noodzakelijk is (art 1653).

- De hulpverlener verstrekt aan derden geen inlichtingen over de patiënt en geeft geen inzage in of afschrift van in het dossier opgenomen bescheiden, dan met toestemming van de patiënt. Onder 'derden' zijn niet begrepen degenen die rechtstreeks bij de behandeling zijn of worden betrokken (medebehandelaar, consulent, vervanger: art 1653l).

- Het toestemmingsvereiste geldt niet voor inlichtingen en inzage ten behoeve van statistisch en ander wetenschappelikk onderzoek op het gebied van de volksgezondheid, indien is voldaan aan vier voorwaarden: (1) het vragen van toestemming is in redelijkheid niet mogelijk, (2) het onderzoek dient een algemeen belang, (3) de gegevens zijn essentiëel voor het uit te voeren onderzoek, en (4) het onderzoek wordt zó uitgevoerd, dat de privacy van de patiënt niet onevenredig wordt geschaad (art 1653m).

- Van het lichaam afgescheiden anonieme stoffen en delen kunnen voor medischstatistisch of ander medisch-wetenschappelik onderzoek worden gebruikt, (1) voor zover de betreffende patiënt tegen zodanig onderzoek geen bezwaar heeft gemaakt, (2) het onderzoek met de vereiste zorgvuldigheid wordt verricht en (3) het bij het onderzoek te gebruiken materiaal en de daaruit te verkrijgen gegevens niet tot de persoon herleidbaar zjjn (art 1653w).

\section{Rapporten van de Nationale Raad voor de Volksgezondheid}

Over bovengenoemde regelgeving heeft met name de Nationale Raad voor de Volksgezondheid een relatief groot aantal rapporten uitgebracht. In totaal, exclusief de bijlagen, 252 pagina's tekst A4.

\section{Advies geneeskundige behandelingsovereenkomst}

In het advies van september 1987 inzake het voorontwerp WGBO wordt het zonder expliciete toestemming van de patiënt doorgeven van diens medische gegevens aan wetenschappelijke, statistische of epidemiologische centra onjuist geacht ('Als deze gegevens al geanonimiseerd zijn, zj]n deze niettemin vrij eenvoudig tot de individuele patiënt te herleiden'). Aanbevolen wordt, aan het begin van een hulpverteningsovereenkomst in een toestemmingsformulier schriftelijk vast te leggen, dat de patiënt zijn toestemming geeft voor het doorge- 
ven van bepaalde informatie aan bepaalde derden gedurende de duur van de hulpverlening.

Ten aanzien van het zonder toestemming doorgegeven van medische persoonsgegevens ten behoeve van wetenschappelijk onderzoek wordt aangegeven dat de daarbij gestelde vier voorwaarden eng moeten worden ge ïterpreteerd en zelfs moeten worden aangescherpt, en dienen te worden aangevuld met de bepalingen, (5) dat vast moet staan dat het onderzoek niet in de vorm van tot de patiënt herleidbare gegevens zal worden gepresenteerd, (6) dat het onderzoek wordt verricht volgens een op de onderzoeker betrekking hebbende beroepscode (opgesteld door wetenschappelijke instituten) en (7) nadat een daartoe ingestelde onafhankelijke commissie (bijvoorbeeld een medisch-ethische toetsingscommissie) over de privacy-aspecten van het onderzoek positief heeft geadviseerd (deze voorwaarde is in een advies van maart 1992 wat genuanceerd).

Deze zeven voorwaarden zouden op overeenkomstige wijze moeten gelden voor wetenschappelijk onderzoek door hulpverleners die de benodigde gegevens reeds onder zich hebben, daar deze verkregen zijn voor een ander doel. NB Deze stelling is in het advies van maart 1992 aanmerkelijk verzwaktl

\section{Advies gebruik van privacyreglementen}

De model-privacyreglementen, opgenomen in het advies van september 1988, voegen met betrekking tot het zonder toestemming doorgeven van medische persoonsgegevens voor wetenschappelijk onderzoek nog een drietal voorwaarden toe: (8) tussen de houder en de onderzoeker dienen deugdelijke afspraken te zjin gemaakt over de in verband met de privacybescherming van geregistreerden te treffen maatregelen, (9) de houder dient zich in deze zin in voldoende mate jegens de geregistreerde tegen aansprakelijkheid te hebben gevrijwaard en (10) van een dergelijke gegevensverstrekking wordt door de houder een register (welke gegevens, aan wie, over wie, voor welke doeleinden, wanneer, zijn verstrekt) bijgehouden en gedurende twee jaren bewaard.

\section{Rapport ervaringen met NRV-model-privacyreglementen}

In het rapport over de envaringen met de model-privacyreglementen van april 1990 wordt gesignaleerd, dat de eis van de WPR, dat geregistreerden vooraf ervan op de hoogte moeten worden gesteld dat de persoonsregistratie voor andere doelen dan zorgverlening, bijvoorbeeld voor wetenschappelijk onderzoek, wordt gebruikt, problemen oplevert met betrekking tot geregistreerden waarvan het medisch dossier is afgesloten. Het anonimiseren van deze dossiers is in de praktijk niet realiseerbaar.

\section{$4 \quad$ Advies normering onderzoek met lichaamsmateriaal}

Vooral dit rapport van mei 1991, waarin de vraag naar een eventuele normering van medisch-wetenschappelijk onderzoek met humaan restmateriaal ter sprake komt, is van belang.

Gewezen wordt op de drie beginselen die bij de afweging van individueel versus algemeen belang centraal staan: (1) informed consent, (2) privacybescherming van de patiënt en (3) algemeen belang van een goede volksgezondheid/gezond- 
heidszorg, waarvoor wetenschappelijk onderzoek is vereist.

De standpunten van gezaghebbende gezondheidsjuristen over 'gebruik voor een ander doel' worden als volgt samengevat:

- Roscam Abbing (1989): In het kader van de gezondheidszorg mogen niet méér gegevens worden vastgelegd en niet langer blijen bewaard, dan voor het concrete behandelingsdoel noodzakelijk is. De gegevens moeten rechtmatig zijn verkregen en mogen zonder toestemming van betrokkene niet voor een ander doel worden aangewend.

- Gevers (1990): Degene van wie het lichaamsmateriaal afkomstig is behoudt in beginsel de zeggenschap daarover.

- Olsthoorn-Heim (1990): Bij onderzoek met tot een persoon herleidbaar restmateriaal is dit materiaal drager van persoonsgegevens en valt derhalve onder de bescherming van art 10 Grondwet (privacybescherming); bij onderzoek met anoniem materiaal komt wellicht art 11 Grondwet (onaantastbaarheid van het menselijk lichaam) in het geding; bij gebruik voor een ander doel gaat het in wezen om het in beide artikelen besloten (relatieve) zelfbeschikkingsrecht. Dit recht kan op verschillende wijzen worden vormgegeven: (1) via het verplichtstellen van uitdrukkelijke toestemming voor een specifiek doel, (2) via een generale machtiging voor een nauwelijks gedefiniëerd doel (of een globale toestemming voor een breed omschreven onderzoeksdoel) of (3) via het geven van informatie over mogelijke gebruiksdoelen, met de mogelijkheid voor betrokkene bezwaar te maken.

Onder het kopje 'Opinies van onderzoekers' wordt verwezen naar publicaties van medici en medische onderzoekers waarin kritiek wordt geuit op de te sterke accentuering van zelfbeschikking in de gezondheidsethiek en het gezondheidsrecht:

- Vandenbroucke (1990): De opstelling van beide disciplines werpt belemmeringen op voor zinvol onderzoek op bijvoorbeeld epidemiologisch, klinisch en pathologisch-anatomisch gebied.

- Bosman (1990): De patiënt die geneeskundige behandeling zoekt vraagt om inzet van ervaring, verkregen bij eerdere patiënten, en is daarmee moreel verplicht de ervaringen die de arts ontleent aan zijn ziekte aan het totaal van ervaringsfeiten toe to voegen.

- Dunning (1990): Vele medici vragen zich af of het gezondheidsrecht het individuele zelfbeschikkingsrecht in relatie tot het sociale recht op een goede gezondheidszorg niet te zeer verabsoluteert, tot schade van de gemeenschap en van de bescherming van andere individuen. Het begrip 'zelfbeschikking van de patiënt' is in het recht pas laat tot uitdrukking gekomen en wacht ook nu nog op een goede omschrijving en afgrenzing. Voor die zelfbeschikking koos de patiënt zich als regel in goed vertrouwen een arts die zijn belangen behartigde, omdat or deskundigheid zowel als inspanning impliciet werden toegezegd. De formalisering en juridisering van de zelfbeschikking beïnvloeden ook het contact tussen arts en patiënt als vertrouwensrelatie, vooral wanneer de arts tevens wordt gezien als schader en schender van de individuele rechten.

In hoofdstuk 5 wordt het standpunt van de raad inzake de normering van medisch-wetenschappelijk onderzoek met humaan restmateriaal geformuleerd. 
Daarbij wordt onderscheid gemaakt tussen: onderzoek met anoniem lichaamsmateriaal en onderzoek met niet-anoniem materiaal, verricht door derden of door de (mede-)behandelaar:

- Wetenschappelijk onderzoek met anoniem lichaamsmateriaal

Grote zorgvuldigheid is nodig bij de opzet en uitvoering van het onderzoek en bij de publicatie van de resultaten, te realiseren door zelfregulering. Daarom dient in art 1653w WGBO als extra voorwaarde te worden opgenomen, dat het onderzoek moet worden uitgevoerd volgens een onderzoekscode.

Teneinde aan het geen-bezwaarsysteem inhoud te geven, zal aan de kans dat wetenschappelijk onderzoek op humaan restmateriaal wordt verricht en aan het feit dat men daartegen bezwaar kan maken, in voldoende mate aandacht moeten worden besteed. Dit is een taak voor veld én overheid!

\section{- Wetenschappelijk onderzoek met niet-anoniem lichaamsmateriaal}

a Onderzoek verricht door derden:

In deze gevallen geldt een normering conform die voor wetenschappelijk onderzoek met medische persoonsgegevens, dus: toestemming vereist (kan in de vorm van een globale toestemming of generale machtiging). Zonder toestemming alieen indien is voldaan aan alle vereisten van art $1653 \mathrm{~m}$ WGBO, inclusief de verplichting dat het onderzoek volgens een onderzoekscode wordt uitgevoerd.

b Onderzoek verricht door behandelend arts of medebehandelaar Ten aanzien van lichaamsmateriaal (voor onderzoek met patiëntgegevens geen toestemming nodigl) zou de behandelaar niet zonder meer mogen uitgaan van het geen-bezwaarsysteem. Wél indien het gaat om incidenteel gebruik dat dicht tegen de oorspronkeljke bestemming aanligt, en wél indien het gaat om wetenschappelijk onderzoek dat binnen bepaalde grenzen blijt, zoals bijvoorbeeld incidenteel gebruik om een nieuwe nog niet volledig uitgekristalliseerde onderzoeksvraag of een vage hypothese uit te testen.

Wanneer van te voren bekend is dat met het lichaamsmateriaal, naast dat voor de oorspronkelijke doelstelling, ook ander onderzoek zal worden verricht, dient ten minste globale toestemming te worden gevraagd. Indien later een andere bestemming in zicht komt die ver van de oorspronkelijke afstaat, dient voor het gebruik van reeds beschikbaar materiaal alsnog expliciet toestemming te worden gevraagd.

In al deze gevallen zal het onderzoek zoveel mogelijk op indirect herteidbaar (via een sleutel of code) materiaal moeten worden uitgevoerd en de onderzoekerbehandelaar moet zich houden aan een onderzoekscode.

In het advies wordt voorgesteld de zorgvuldigheidseis bij gebruik van anoniem lichaamsmateriaal (art 1653w WGBO) te concretiseren in het vereiste, dat het onderzoek wordt verricht volgens een door de representatieve organisaties vastgestelde code voor het doen van medisch-wetenschappelijk onderzoek.

In bijlage 5 nemen vier adviserende leden van de werkgroep die het rapport heeft voorbereid, werkzaam in het medisch onderzoek en in de medische praktjk, 
afstand van het rapport, dat naar hun mening te eenzijdig op één aspect, het wetenschappelijk onderzoek, is gericht. Onvoldoende aandacht wordt geschonken aan andere aspecten van de geneeskunde zoals de patiëntenzorg, de kwaliteitscontrole en het onderwijs, en de onderlinge verbondenheid van deze aspecten wordt niet onderkend.

Het advies is naar hun mening sterk restrictief geformuleerd, ook al worden uitzonderingen genoemd en ontsnappingswegen aangegeven. Dit zal onvermijdelijk leiden tot een massaal gebruik hiervan, waarop controle nauwelijks mogelijk is. Aldus komt de geloofwaardigheid van alle betrokkenen en van de getroffen regelingen in het gedrang en zullen uiteindelijk alle partijen - inclusief de patiënt verliezers zijn.

Deze leden onderschrijen de principes van privacy, van informed consent en van het zelffeschikkingsrecht van de patiënt. Daarop sluiten echter aan: de noodzaak van directe zorg, van kwaliteitscontrole, van onderwijs en van wetenschappelijk onderzoek. Deze onderdelen zjjn nauw verstrengeld en dienen dat ook te zjjn. Het isoleren van één van deze aspecten uit het geheel zal ernstige gevolgen hebben voor de volksgezondheid.

\section{$4 \quad$ Een zaak van later zorg?}

Februari 1992 verscheen het verslag van een casusbespreking normering wetenschappelijk onderzoek met lichaamsmateriaal. Om te kunnen nagaan of de door de raad voorgestelde regeling, vertaald in een beslisboom met een zo expliciet mogelijke weergave van de te nemen stappen, in de praktijk kan werken, boog op 28-11-91 een vijttigtal deskundigen zich over een aantal onderzoekcases. Van de belangrijkste daarbij gebleken knelpunten wordt een overzicht gegeven.

Onderzoekers worden met toestemmingsbepalingen geconfronteerd waarvan onduidelijk is of de mensen die wel willen. Er is geen onderzoek bekend naar de vraag of mensen het vervelend vinden wanneer blijkt dat hun gegevens buiten hun medeweten voor wetenschappelijk onderzoek zijn gebruikt.

De meeste onderzoekers zouden het liefst het geen-bezwaarsysteem, dat in het wetsvoorstel alleen geldt voor anoniem gebruik van lichaamsstoffen, algemene werking verlenen. Een dergelijk systeem (evenals 'veronderstelde toestemming') staat of valt met goed geïnformeerd zijn; op zijn minst: 'het hebben kunnen weten'.

- Bosman: In ieder geval moet het profijt duidelijk worden gemaakt dat de patiënt zelf en anderen hebben van geneeskundig onderzoek als integraal onderdeel van geneeskundig handelen. Patiënten zijn zich er vaak niet van bewust dat hun gegevens ook voor onderzoek worden gebruikt, en dat zulks ook vanzelf spreekt, omdat het onderscheid tussen patiëntenzorg en wetenschappelijk onderzoek volstrekt artificieel is.

- Gevers: Deze twee zaken laten zich heel wel onderscheiden. Dat in een enkel geval de grenslijn niet precies valt te trekken, doet aan het praktische en juridjsche belang van het onderscheid niet af. 
gegevensverstrekking ten behoeve van wetenschappelijk onderzoek; de voorgeschreven handelwijze wordt in een complex ogend beslisschema samengevat.

a Als kan worden volstaan met (door de ontvanger/onderzoeker) niet tot een persoon herleidbare gegevens is geen toestemming van de geregistreerde nodig.

b Voor veel observatione日l medisch-wetenschappelijk onderzoek is wel inzage in patiëntgegevens nodig. Dit soort onderzoekingen maakt een integraal onderdeel uit van de geneeskunde. Inzage van medische persoonsgegevens door een onderzoeker, niet zijnde de behandelaar, moet gezien worden als een verstrekking aan derden, waarvoor in principe (globale) toestemming (bij voorkeur na informatie over: doel, belang, methode, tijdsduur, onderzoeker/onderzoeksinstantiel) van de patiënt nodig is, en wel schriftelijk. Hiervan kan in bepaalde gevallen, mits verder wordt voldaan aan de door de raad aangevulde voorwaarden van art 1653w WGBO, worden afgezien: patiënt overleden, niet meer traceerbaar, ook na rappel geen reactie, niet in staat tot een redelijke waardering van zijn belangen en geen (wettelijke) vertegenwoordiger.

C Voor medisch-wetenschappelijk onderzoek, verricht door de behandelaar die zeff de benodige patiëntgegevens reeds onder zich heeft, is geen toestemming van de geregistreerde noodzakelijk. Volgens de raad zou de behandelaar, ingeval tevoren bekend is dat hij de gegevens zal gebruiken voor wetenschappelik onderzoek, een globale toestemming moeten vragen. Indien daartoe later wordt besloten en het uit te voeren onderzoek ver afstaat van het oorspronkelijk gedefiniëerde doel, zou alsnog gerichte toestemming moeten worden gevraagd.

d Als er sprake is van wetenschappelik onderzoek dat 'een hoge graad van ethische of maatschappelijke gevoeligheid' kent en waatij publicatie van de resultaten kan leiden tot ongewenste discriminatoire effecten ten opzichte van bepaalde groeperingen in de samenleving, acht de raad contact met belangengroeperingen wenselijk. Het betreffende onderzoeksvoorstel en eventueel het resultaat van bovenbedoeld overleg dienen aan een medisch-ethische toetsingscommissie te worden voorgelegd.

- Ten aanzien van steekproeven in het kader van wetenschappelijk onderzoek komt de raad tot de conclusie, dat onder bepaaide voorwaarden de steekproeftrekking op het op naam gestelde basismateriaal door de onderzoeker (voor wie dan een afgeleid beroepsgeheim geldt) zonder toestemming van (alle) geregistreerden kan worden verricht. Vereisten: (1) Voorafgaand aan de steekproeftrekking dient een onafhankelijke commissie te hebben ingestemd met deze activiteit, (2) de trekking zelf dient te worden verricht conform een op de onderzoeker betrekking hebbende gedragscode, (3) vervolgens dient het onderzoek zelf te geschieden op basis van geanonimiseerde gegevens, (d) zoniet dan dient voor dit gebruik toestemming van de geselecteerde geregistreerden te worden gevraagd.

Privacyreglementen en codes

Privacyreglementen: twee voorbeelden 
In $\S 5$ van de WPR wordt bepaald, dat door de houders van bepaalde persoonsregistraties, waaronder die op het gebied van de gezondheidszorg, reglementen moeten worden vastgesteld, waarin de werking van de persoonsregistratie is beschreven. Dit reglement dient een duidelijke regeling te bevatten van onderwerpen zoals: het doel van de registratie; de categorieën personen over wie welke soorten gegevens in de registratie worden opgenomen en hoe deze worden verkregen; de categorieën van personen en instanties waaraan welke soorten gegevens uit de registratie worden verstrekt en op welke wijze geregistreerden hierover mededeling kunnen verkrijgen; de rechtstreeks toegang tot de registratie.

De hierboven achter 2 en $\underline{3}$ genoemde rapporten van de Nationale Raad bevatten modelreglementen waarin met deze bepalingen én met hetgeen ter zake in de WGBO is opgenomen, rekening is gehouden. Gezondheidsinstellingen en beroepsbeoefenaren werden geadviseerd, hun privacyreglementen zoveel mogelijk te enten op deze modellen.

\section{Academisch Ziekenhuis Maastricht}

Het azM heeft een gemeenschappelijk privacyreglement met vijf bijlagen opgesteld; geldend voor alle categorieën registraties waarin medische en psychologische gegevens van patiënten zijn opgenomen. Het stuk bevat 21 artikelen (86 artikelleden) op 14 pagina's A4; de bijlagen beslaan 39 bladzijden A4. Het reglement ligt ter inzage bij het Patiënten-informatiecentrum; tegen kostprijs kunnen afschriften worden verkregen. In de 'Opnamewijzer azM' wordt in het hoofdstuk over 'Rechten, plichten en privacy' naar het reglement verwezen. Over het verstrekken en gebruiken van patiëntgegevens voor andere doelen staat in deze info niets vermeld.

Als één van de (mogelijke) doelen van de persoonsregistraties wordt genoemd: het vastleggen en beschikbaar stellen van informatie ten behoeve van wetenschappelijk onderwijs en onderzoek.

- Aan personen binnen de instelling kunnen patiëntgegevens worden verstrekt ten behoeve van wetenschappelijk onderzoek, mits er aan negen voorwaarden is voldaan. Deze betreffen de vier bepalingen van art $1653 \mathrm{~m}$ WGBO, aangevuld met o.a.: het onderzoek wordt verricht conform een op de onderzoeker betrekking hebbende gedragscode; de medisch-ethische commissie heeft over het onderzoek een positief advies uitgebracht; tussen houder en onderzoeker zijn deugdelijke afspraken gemaakt over in verband met privacybescherming te treffen maatregelen. Indien gegevens zodanig zijn geanonimiseerd dat zj] niet meer tot individuele personen herleidbaar zj]n, kan de houder, met inachtneming van het advies van de Medisch Ethische Commissie, beslissen deze te verstrekken ten behoeve van wetenschappelijk onderzoek. Van gegevensverstrekking in het kader van wetenschappelijk onderzoek wordt door de houder een register bijgehouden. De hierin vermelde gegeven worden gedurende twee kalenderjaren bewaard.

- Soortgelijke bepalingen betreffende wetenschappelijk onderzoek komen niet voor onder het kopje 'Exteme gegevensverstrekking'. Aangenomen moet daarom worden, dat het aan onderzoekers buiten de instelling verstrekken van persoonsgegevens uitsluitend met toestemming van de geregistreerde, neergelegd in een 
bij de houder gedeponeerde verklaring, kan plaatsvinden.

\section{Catharina-ziekenhuis Eindhoven}

Voor de patiëntenregistratie van medisch specialisten, de verpleegkundige patiëntenregistratie, de paramedische patiëntenregistraties en de overige geautomatiseerde persoonsregistraties zjin afzonderlijke privacyreglementen opgesteld. Het privacyreglement voor de medisch specialisten telt 9 artikelen ( 40 artikeileden) en beslaat 8 pagina's A4. Er zijn twee bijlagen van in totaal twee bladzijden. Het reglement kan 0.a. worden ingezien op het bureau patiëntenbelangen, welk bureau ook kan zorgdragen voor copieën. In het reglement wordt aangegeven dat over de opslag en het gebruik van medische gegevens zowel in de algemene patiënteninformatie van het ziekenhuis als in folders op polikliniek- en verpleegafdeligen relevante informatie wordt verstrekt. Bijlage 2 geeft voor deze informatie een tekstvoorbeeld. Daarin komt de volgende passage voor:

'Voor medisch-wetenschappelijk onderzoek en voor beleid en planning op het terrein van de gezondheidszorg zijn veel gegevens over patiënten, ziekten en ongevallen nodig. In het algemeen worden deze in een zodanige vorm verstrekt of daarna bewerkt, dat ze niet meer tot een bepaalde patiënt herleidbaar zijn. Indien dit niet mogelijk is, wordt voor dit gebruik uw toestemming gevraagd.'

In het reglement wordt als nevendoel van de patiëntenregistratie genoemd: ondersteuning van en gebruik bij klinisch-wetenschappelijk onderzoek. Wat het verstrekken van gegevens uit de registratie voor dit doel betreft, wordt bepaald: - Aanvragen om inzage of copie van (onderdelen van) een cumulatief medisch dossier dienen schriftelijk te worden gericht aan (een representant van het specialisme van) de auteur.

- Voor de verstrekking van patiëntgegevens ten behoeve van wetenschappelijk onderzoek is instemming van de betreffende geregistreerde(n) vereist. Verstrekking zonder toestemming kan plaatsvinden indien aan viff voorwaarden is voldaan: de vier genoemd in art $1653 \mathrm{~m}$ WGBO, aangevuld met: dat de uitkomsten waarvoor de gegevens worden gebruikt niet meer tot inviduele personen herleidbaar zijn.

- Voor de verstrekking van medische gegevens ten behoeve van wetenschappelijk onderzoek, welke zodanig zijn geanonimiseerd dat zij redelijkerwijs niet tot Inviduele personen herleidbaar zijn, is geen instemming van de geregistreerden vereist.

\section{Codes: twee voorbeelden}

In art 1 en 15 van de Wet persoonsregistraties wordt gesproken over gedragscodes, opgesteld door voor een bepaalde sector representatieve organisaties, met regels ter bescherming van de privacy en aanbevelingen ten aanzien van persoonsregistraties. Een dergelijke code kan door de Registratiekamer worden erkend als in overeenstemming met de strekking van de wettelijke bepalingen. De Nationale Raad heeft het begrip onderzoekscode ge ïntroduceerd als één van de voorwaarden waaraan moet zijn voldaan wil wetenschappelijk onderzoek met medische persoonsgegevens of met humaan restmateriaal zonder toestemming van de betreffende patiënt mogen plaatsvinden. 
Het verschil tussen deze codes wordt als volgt aangegeven:

Een gedragscode richt zich tot en geeft regels voor een individu in een bepaalde hoedanigheid. Het toezicht op de naleving ligt bij de opsteller, in de regel een wetenschappelijke of beroepsvereniging. Alleen de leden van deze vereniging zijn aan de code gebonden.

Een onderzoekscode richt zich tot allen die onderzoek overwegen of daaraan meewerken en kan aparte normen bevatten voor bijvoorbeeld de opdrachtgever, de subsidiënt, de instelling waarbinnen het onderzoek plaatsvindt, de onderzoekersleider en voor overige betrokkenen. Het toezicht op de naleving van een onderzoekscode kan plaatsvinden door de vereniging, de instelling, de subsidiënt of de inspectie. Het 'regelbereik' van deze code ligt dus hoger.

De Nationale Raad meent dat in een onderzoekscode (met betrekking tot wetenschappelijk onderzoek met humaan restmateriaal) ten minste moet worden bepaald:

- dat bij onderzoek met anoniem materiaal de anonimiteit gewaarborgd blijft en dat de opdrachtgever en de onderzoeksleider zich ervan vergewissen dat patiëntenvoorlichting betreffende het geen-bezwaarsysteem in voldoende mate heeft plaatsgevonden;

- dat bij onderzoek met niet-anoniem materiaal dit zoveel mogelijk indirect herleidbaar (via een code en sleutel) wordt gemaakt en dat de onderzoeksleider zich ervan vergewist dat globale toestemming tot gebruik van het materiaal is verkregen;

- in welke gevallen onderzoek overeenkomstig de uitzonderingsbepalingen van art $1653 m$ WGBO mag worden verricht;

- welke bewaartermijn voor humaan restmateriaal geldt;

- hoe de geheimhoudingsplicht van allen die bij het onderzoek zijn betrokken is geregeld;

- dat bij publicatie van maatschappelijk gevoelig onderzoek de grootst mogelijke zorgvuldigheid wordt betracht en eventueel overleg met belangengroeperingen plaatsvindt;

- in welke gevallen toetsing door een medisch-ethische commissie is verplicht;

- welke regeling voor de behandeling van klachten is getroffen.

Bij de uitwerking hievvan zou de Raad voor Gezondheidsonderzoek en bij de maatschappelijke toetsing en publicatie de Werkgroep Privacy van de Nationale Raad kunnen worden betrokken.

\section{VOl-gedragscode persoonsregistraties (Vereniging van Onderzoek Instituten)}

De code telt in totaal 13 artikelen en 56 artikelleden. Wegens een daarvoor geldend ander WPR-regiem worden vier nieuwe begrippen geïntroduceerd: - Tijdelijke persoonsregistraties: aangelegd voor een eenmalig wetenschappelijk onderzoek; de registratie wordt uiterlijk na zes maanden geanonimiseerd (uitgezonderd: geslacht, woonplaats en geboortejaar).

- Duurzame persoonsregistraties: ten behoeve van wetenschappelijk onderzoek; zes maanden na de gegevensverzameling nog gekoppeld aan cq koppelbaar aan gegevens uit een communicatiebestand.

- Communicatiebestand: een gegevensbestand of steekproef waarin ten behoeve van communicatie met onderzochte of te ondervragen personen geen andere 
gegevens dan personalia e.d. zijn opgenomen.

- Onderzoeksbestand: ten behoeve van wetenschappelijk onderzoek aangelegde verzameling samenhangende gegevens die niet herleidbaar zijn tot individuele natuurlijke personen (vallen niet onder de WPR en op deze bestanden is de code niet van toepassing).

Persoonsregistraties met ('gevoelige') gegevens die oorspronkelijk zijn verkregen in een medische behandelsituatie zijn extra beschermd door het beroepsgeheim. Deze kunnen niet worden verkregen/verstrekt, ook niet voor wetenschappelijk onderzoek, zonder nadrukkelijke schriftelijke toestemming van de geregistreerde.

Art 8.2 De houder streeft ernaar om bij het aanleggen van een persoonsregistratie, indien dat redelijkerwijs mogelijk en wetenschappelijk verantwoord is, de beoogde geregistreerden van te voren op de hoogte te stellen van de registratiebepalingen.

Art 11 De houder verstrekt aan derden geen persoonsgegevens uit tijdelijke persoonsregistraties. Uit duurzame persoonsregistraties worden persoonsgegevens alleen aan derden verstrekt onder de volgende voorwaarden: (a) geleverd wordt aan een onderzoeksinstelling en alleen voor wetenschappelijk onderzoek waarvan de uitkomsten niet herleidbaar zijn; (b) de ontvangende instelling handelt met betrekking tot deze persoonsgegevens overeenkomstig de code; (c) tenzij dat om zwaarwegende praktische of onderzoekstechnische redenen redelijkerwijs niet mogelijk is, zijn de betrokken personen op de hoogte gebracht van het voornemen van de houder tot doorlevering; (d) de voorwaarden van doorlevering, o.a. met betrekking tot doel en beheer, worden schriftelijk vastgelegd; $(e)$ doorlevering vindt alleen plaats indien dit geen onevenredige schade zal toebrengen aan de privacy van de geregistreerden; $(f)$ op verzoek van geregistreerde worden diens persoonsgegevens niet doorgeleverd.

Doorlevering van gevoelige persoonsgegevens vindt in beginsel uitsluitend plaats met uitdrukkelijke schriftelijke toestemming van de betreffende geregistreerde.

\section{Proeve van een gedragscode voor gezondheidsonderzoek (RGO)}

Bedoeld voor (a) medisch-natuurwetenschappelijk en patiëntgebonden onderzoek, (b) epidemiologisch onderzoek en (c) gezondheidszorgonderzoek.

De 'proeve' beslaat 66 pagina's A4; de code bestaat uit 23 artikelen (67 artikelleden); er zjjn zes bijlagen.

In de code wordt onderscheid gemaakt tussen:

A-bepalingen, direct ontleend aan of afgeleid van wettelijke bepalingen en vereisten (vorm en inhoud van deze bepalingen staan niet ter discussie), B-bepalingen, die een uitwerking zijn van open normen uit de WPA en de WGBO (onmisbaar voor een code; over de formulering is discussie mogelijk), en C-bepalingen, niet direct geënt op de wetten, maar bijvoorbeeld afgeleid van (ongeschreven) maatschappelijke omgangsnormen.

In belangrijke mate is gebruik gemaakt van de adviezen van de Nationale Raad en van de VOl-gedragscode.

Het is de bedoeling dat dit rapport wordt besproken in een door de Raad voor 
Gezondheidsonderzoek in te stellen commissie, welke representatief geacht kan worden voor het gehele veld van het gezondheidsonderzoek.

\section{Overwegingen}

In de voorgaande paragrafen zijn, zonder commentaar, een aantal op het onderwerp van deze voordracht geselecteerde feitelijkheden weergegeven.

Wie zal niet de conclusie onderschrijven dat de wetgever, overheid en parlement, de landelijke adviesorganen en de taliijke voornamelijk gezondheidsrechtelijke schrijvers (in totaal enkele honderden personen), maar dat geldt in mindere mate ook voor de koepelorganisaties, en de bij de uitwerking en uitvoering betrokken instituten en functionarissen, erin geslaagd zijn, de in twee korte grondwetsartikelen in redelijk begrijpelijke taal neergelegde rechten van individuele burgers, op privacy en op lichamelijke integriteit, te vertalen in een complex, ondoorzichting en nauwelijks toegankelijk bouwsel van wettelijke bepalingen, uitvoeringsmaatregelen, nadere voorwaarden, codes en reglementen, waarvan de einddatum van oplevering nog niet in zicht is, met een zucht naar detaillering en verfijning die zijn weerga niet kent.

Zelfs voor zeer gemotiveerde en bij het onderwerp zelf belanghebbende personen (enkele honderden?) is het nauwelijks mogelijk, zich de inhoud van de formele stukken eigen te maken, de commentaren erop te lezen en de literatuur bij te houden.

Wat dan te denken van degenen voor wie deze regelgeving primair is bedoeld: de burger, vooral in zijn rol als (potentiële) patiënt (en dat zijn er miljoenen), en van degenen voor wie de regelingen grote consequenties hebben voor hun dagelijks werk: de behandelend arts en de instelling, de onderzoeker en het instituut (en dat zijn er tienduizenden).

Is hier sprake van een goed doordacht en samenhangend beleid, zoals omschreven bij de aanvang van deze voordracht ? Op grond van de volgende overwegingen moet het antwoord op deze vraag ontkennend zijn.

a Bij het formuleren van de doelstellingen is onvoldoende gelet op de samenhang met voorgenomen cq in gang gezet beleid op verwant terrein en onvoldoende rekening gehouden met andere gewichtige belangen van individu en samenleving.

b De keuze voor een wettelijke regeling welke uitgaat van en zich primair richt op het veronderstelde (maar niet beargumenteerde of geadstrueerde) belang van het individu, los van de maatschappelijke context waarin deze zich bevindt, lijkt fundamenteel onjuist.

c Bij de (te gedetailleerde) invulling van de regelgeving met betrekking tot de privacybescherming en het recht op zelfbeschikking is onvoldoende gekeken naar cq rekening gehouden met de gevolgen voor de inhoud en het effect van bestaande en toekomstige wetgeving op voor individuele burgers belangrijke gebieden.

d Bij het inhoudelijk uitwerken van dit primaat van het individu voor het gebied 
van de gezondheidszorg en het medisch-wetenschappelijk onderzoek, heeft men zich gedistancieerd van de werkelijkheid van alledag. Naar de wensen en verwachtingen die op dit terrein bij (potentiële) patiënten leven, is geen onderzoek verricht.

e Het toestemmingsrecht van het individu is in beide wetten zo verabsoluteerd en geformaliseerd, dat - nog los van de vraag of de patiënt daar prijs op stelt - het voldoen aan dat recht in de praktijk niet realiseerbaar zal blijken. Voor de behandelend arts brengt de wijze waarop het toestemmingsvereiste met betrekking tot het gebruik van patiëntgegevens en van lichaamsmateriaal voor een ander doel dan de actuele behandeling is uitgewerkt, met zich, dat hij zjin plicht tot het zorgdragen voor een goede individuele gezondheidszorg, voor al zijn patiënten en voor de toekomst, én tot het actief bevorderen van de geneeskunde - beide ook in het belang van de betreffende patiënt! - niet kan waarmaken. Het medischwetenschappelijk onderzoek, met name het toegepaste en het observationele, wordt door de aan verstrekking en gebruik van patiëntgegevens en humaan restmateriaal gestelde voorwaarden en eisen, belemmerd en kostbaarder.

$f$ De implementatie van de wet- en regelgeving in de praktijk verloopt moeizaam. Door de ingewikkeldheid van de voorschriften is in veel instellingen en instituten de verantwoordelijkheid voor de organisatie-specifieke uitwerking en voor de introductie bij betrokken medewerkers in handen gelegd van enkele deskundigen en/of staffunctionarissen. Vrijwel alle artsen en onderzoekers onderschrijven het belang van privacybescherming en van een (relatief) zelfbeschikkingsrecht voor patiënten. De wijze echter waarop deze principes op een aantal onderdelen zijn uitgewerkt, roept bij hen weerstand op tegen het kennisnemen van het geheel der regelingen en tegen het in de praktijk toepassen van niet-betwiste patiëntenrechten.

g Van een systematische evaluatie van zowel het proces van implementatie als van de effecten van de regelgeving voor de bescherming van de persoonlike levenssfeer van patiënten en van hun recht op het geven of onthouden van toestemming voor bijvoorbeeld 'gebruik voor een ander doel' is tot heden geen sprake. Er is daanoor ook geen registratiesysteem ontwikeld.

Er kan geen sluitend antwoord worden gegeven op vragen zoals:

In welke mate zjjn de doelstellingen bereikt; waren de middelen voor het bereiken daarvan inderdaad geëigend en doelmatig; welke kosten heeft een en ander met zich mee gebracht en welke indirecte en onverwachte effecten hebben zich voorgedaan; zijn er niet-gewenste en voor het beoogde of voor verwante doelen nadelige bijwerkingen opgetreden?

De meest wezenlijke vraag is: voldoet de wijze waarop de in de grondwet verankerde rechten van de burger op privacybescherming en behoud van lichamelijke integriteit zijn uitgewerkt en in maatregelen zijn omgezet, in alle opzichten aan datgene wat met deze rechten wordt beoogd, en aan datgene wat burgers wensen en, gezien de andere belangen van individu en samenleving, redelijkerwijs mogen verwachten?

\section{Aanbevelingen}

De in de paragraaf 'overwegingen' geuite kritiek krijgt meer betekenis als in kort 
bestek de hoofdzaken van een zelfordenings-regeling kunnen worden geschetst welke in de praktijk goed hanteerbaar is en recht doet aan zowel de belangen van de patiënt wat betreft diens privacybescherming en zijn recht op zelfbeschikking als aan de belangen van een goede gezondheidszorg en van verantwoord medisch-wetenschappelijk onderzoek, gericht op bevordering van de geneeskunde.

\section{Informatie}

Het is noodzakelijk dat zowel landelijk als op het niveau van instellingen en van individuele praktijken en samenwerkingsverbanden, op burger en patiënt gerichte schriftelijke informatie in begrijpelijke taal wordt opgesteld en verspreid,

a over de betekenis van goed medisch-wetenschappelijk onderzoek voor de kwaliteit van de gezondheidszorg, via het verkrijgen van meer inzicht in aspecten van gezondheid en ziekten en ten behoeve van de ontwikkeling en evaluatie van methoden en technieken voor preventie, diagnostiek en therapie;

b over de noodzaak van het voor de uitvoering van dergelijk onderzoek kunnen beschikken over medische gegevens en over humaan restmateriaal, verkregen in de curatieve sector;

c over de verplichting van behandelend artsen, zich niet alleen in te zetten voor de behandeling van actuele patiënten, maar ook bij te dragen aan een goede gezondheidszorg in heden en toekomst en aan de bevordering van de geneeskunde;

d over de zorgvuldigheid waarmee bij het voor dit doel verstrekken en gebruiken van gegevens en materiaal en bij de publicatie van de onderzoeksresultaten rekening wordt gehouden met de bescherming van de privacy, met name door er voor zorg te dragen dat de gegevens en het materiaal voor personen buiten de actuele behandelingsituatie niet tot de betreffende patiënten herleidbaar zijn;

e over het feit dat de behandelend artsen, tenzij het tegendeel blijkt - bijvoorbeeld als een patiënt aangeeft bezwaar te hebben tegen het verstrekken van bepaalde gegevens of van bepaald materiaal aan bepaalde derden of tegen het gebruik voor een bepaald doel - aannemen dat hun patiënten instemmen met het voor dit doel beschikbaar houden, stellen en gebruiken van patiëntgegevens en van humaan restmateriaal.

\section{Gebruik door bil onderzoek en behandeling betrokken professionals}

Bij gebruik van patiëntgegevens of van lichaamsmateriaal voor medisch-wetenschappelijk onderzoek door degene (cq diens functionele eenheid) die deze gegevens of dit materiaal reeds onder zich heeft, is anonimisering, in de zin van het vervangen van voor de herleiding tot de betreffende patiënt essentiële gegevens door een code, alleen nodig als tijdens het onderzoek derden toegang hebben tot de gegevens en het materiaal. De sleutel om codes tot patiënten te herleiden mag voor deze derden niet toegankelijk zijn. 
Voorafgaand aan het verstrekken van geselecteerde patiëntgegevens en van bepaald humaan restmateriaal voor medisch-wetenschappelijk onderzoek aan derden, moeten in beginsel deze gegevens en dit materiaal worden geanonimiseerd op de wijze als bij 2 is aangegeven.

Dit selecteren en anonimiseren kan geschieden door één van de bij het onderzoek direct betrokken professionals (afgeleid beroepsgeheim), mits de sleutel daarna alieen in handen komt en blift van de behandelaar en een zodanige methode van coderen is gekozen dat alleen met behulp van deze sleutel herleiding mogelijk is.

Voor het verkrijgen van aanvullende gegevens of van meer of ander materiaal, zal de onderzoeker zich dus, met vermelding van de code, moeten wenden tot de behandelaar. Op deze manier kan ook bij het onderzoek verkregen informatie worden doorgegeven, waarvan mag worden verwacht dat die van belang is voor de (verdere behandeling van) de betreffende patiënt.

Als de aard van het medisch-wetenschappelijk onderzoek vereist, dat tot een individuele patiënt herleidbare gegevens of lichaamsmateriaal worden verstrekt aan en gebruikt door derden, zal de in 1 bedoelde informatie op meer concrete wijze op dit soort onderzoekingen moeten zijn gericht, om het geen-bezwaarstelsel reële inhoud te geven.

Indien deze informatie niet vooraf werd cq kon worden gegeven zal het wetenschappelijk onderzoek alleen kunnen worden verricht als redelijkerwijs wordt voldaan aan de in art $1653 \mathrm{~m}$ genoemde voorwaarden, zoniet, dan alleen nadat alsnog instemming is verkregen van de betreffende patiënten.

4 Gebruik voor ander wetenschappelijk onderzoek

Als medische gegevens of lichaamsmateriaal worden gevraagd en/of gebruikt voor wetenschappelijk onderzoek buiten het terrein of het belang van de volksgezondheid, de gezondheidszorg en de geneeskunde, of voor rechtstreeks op profit gericht 'commercieel' onderzoek is het bovenstaande niet van toepassing.

Over opzet en aanvaardbaarheid van een dergeiijk onderzoek zal in beginsel het oordeel moeten worden gevraagd van een onafhankelijke commissie van deskundigen. In ieder geval (a) zullen de betreffende patiënten adekwaat moeten worden geïnformeerd over doel, belang, aard, werkwijze, e.d. van het onderzoek, (b) zal hun instemming moeten worden gevraagd en verkregen en (c) zullen alleen de voor het onderzoek noodzakelijke gegevens en het materiaal kunnen worden verstrekt, (d) nadat deze door de behandelaar zeff zijn geanonimiseerd.

\section{Tenslotte}

Het gaat niet om het belang van de individuele patiënt versus dat van de samenleving; het gaat om verschillende belangen van hetzelfde individu en van de samenleving (Van der Maas, 1990).

ik heb gezegd. 


\section{BRONNEN}

\section{Wetgeving}

Grondwet (herziening 1983)

Wet persoonsregistratles (28-12-88)

Ultwoeringsregelingen:

- Besluit tot vaststelling Inwerkingtreding onderdelen WPR (8-5-89)

- Beslult tot aanwijzing van niet onder de WPR vallende persoonsregistraties (16-6-89)

- Beslult tot uitvoering artikel 17, onder b en c, WPR (19-12-89)

- Besluit genormeerde vrijstelling (2-1-90)

- Ontwerp-besluit gevoelige gegevens (Staatscourant van 6-6-90)

Op 3-4-92 door ministerraad goedgekeurd; voor advies naar Raad van State

Wet geneeskundige behandelingsovereenkomst

- Voorontwerp (februari 1987)

- Voorstel van wet (29-5-90; laatste wijziging 20-8-91)

Wet inzake medlsche experimenten

- Concept-voorstel (december 1987)

- Voorstel van wet (18-4-92)

- Voorstel voor een wettelijke regeling van experimenten met embryo's Op 6-5-92 voor advies naar Raad van State

\section{Overheldspublicaties}

- Deregulering van overheidsregelingen. Eindbericht van de commissie vermindering en vereenvoudiging van overheldsregelingen (minister van (ustitie, maart 1984)

- Zlcht op wetgeving (minister van justtie, maart 1991)

- $H$ Vutjsje: Mens, erger je niet. Privacybescherming en wetenschappelijk onderzoek (ministerie van onderwijs en wetenschappen, Januari 1992)

\section{Rapporten advlesorganen}

\section{Centrale Raad voor de Volksgezondheid}

- Deeladvies betreffende de jurldische relatle tussen pattënt en arts, het recht van de patlënt op informatle en het toestemmingsvereiste (augustus 1980)

- Deeladvies inzake medische experimenten met mensen (maart 1982)

\section{Nationale Read voor de Volksgezondheld}

- Advies geneeskundige behandelingsovereenkomst (september 1987, publ 4115-50)

- Nota bouwstenen beroepscodes en gedragsregels (september 1988, publ 22/'88)

- Advies gebruik van privacyreglementen (september 1988, publ 19/'88)

- Advies medische experimenten (october 1988, publ 27/'88)

- Rapport ervaringen met NRV-model-privacyreglementen (april 1990, publ 7/'90)

- Commentaar consequenties WGBO voor privacyreglementering (november 1990, publ

30/'90)

- Advies normering onderzoek met lichaamsmaterlaal (mel 1991, publ 11/'91)

- Een zaak van later zorg? Verslag van de casusbespreking normering wetenschappelijk onderzoek met lichaamsmateriaal (februari 1992, publ 4/'92)

- Advies privacy en gegevensverstrekking (maart 1992, publ 9/'92) 
Gezondheidsraad

- Advies inzake registratle van medische en psychologische gegevens en de bescherming van de persoonlijke levenssieer (privacy) (november 1978)

- Advies inzake beschlkbaarstelling en gebruik van foetussen, foetaal weefsel of andere stoffelljke resten na abortus, voor wetenschappelijke doeleinden (september 1984)

- Erfelifkheid: maatschappi] en wetenschap. Over de mogellifheden en grenzen van erfellikheldsdlagnostlek en gentherapie (december 1989)

\section{Privacyreglementen}

- Reglement ter bescherming van de persoonlljke levenssfeer in verband met registraties van medische en psychologische gegevens van patiënten in het Academisch Zlekenhuls Maastricht, met vift bijlagen (1-1-91)

- Privacyreglement patiëntenregistratle Medisch Speciallsten Catharlna-Zlekenhuis Eindhoven, met twee bijlagen (1-7-90)

\section{Gedragscodes}

- VOI-gedragscode persoonsregistratles. Code voor de sector van het non-profit onderzoek-Inopdracht in de gedrags- en maatschappi/wetenschappen (Staatscourant van 8-5-91)

- Proeve van een gedragscode voor gezondheidsonderzoek. Ontwerp voor een gedragscode op basis van de Wet persoonsregistraties en het voorstel van Wet inzake de geneeskundige behandellngsovereenkomst, samengesteld door de Oriëntatiecommissle gedragscode epldemiologisch en gezondheidszorgonderzoek (Raad voor Gezondheldsonderzoek, lanuarl 1992).

\section{Veel geciteerde auteurs}

F T Bosman (e.a.)

- Wetenschappelijk onderzoek en prlvacy. Ned TIjdschr Geneesk 1991: 135:1459

- WGBO en wetenschappelijk onderzoek. Medisch Contact 1991; 46:1238

G Brutel de la Rlvlère

- Medische (persoons)gegevens, lichaamsmaterlaal en wetenschappelljk onderzoek. Tijdschr Gezondheidsr 1990; 14:194 (met naschrlft H D C Roscam Abbing)

- De meerwaarde van medische diagnostlek; jurldische belemmeringen van klinisch wetenschappelijk onderzoek. Ned Tijdschr Geneesk 1991; 135:1049

\section{R M S Doppegleter}

- Medische gegevens en lichaamsmateriaal voor wetenschappelljk onderzoek. Medisch Contact 1991; 46:1081

\section{A J Dunning}

- Grensconflicten in de zorg. In: J K M Gevers en J H Hubben (red) Grenzen aan de zorg; zorgen aan de grens. Alphen aan den Rljn 1990

\section{J K M Gevers}

- Beschikken over cellen en weefsels (Inaugurale rede UVA, Januarl 1990)

- Wetenschappelijk onderzoek en prlvacy. Ned Tijdschr Geneesk 1991; 135:1458

- Het medisch beroepsgeheim: continu ïteit en ontwikkeling. Privacy en registratle 1992; 17:22

H J J Leenen en HDC Roscam Abbing

- Wetenschappeiljk onderzoek en privacy. Ned Tljdschr Geneesk 1991; 135:769+1098+1241

\section{P J van der Maas}

- Privacy-bescherming: een bedreiging voor de volksgezondheid? In: L Boon (red): Privacy in 
de gezondheidszorg. Amstelveen 1990

J C M Mastboom

- Toestemming bedreigt wetenschappelijk onderzoek. Tijdschr Soc Gezondheldsz 1989; 67:127

E T M Olsthoorn-Helm

- Lichaamsmateriaal, epidemiologisch onderzoek en toestemming; de discussie, de argumenten, een conclusle. Tljdschr Gezondheidsr 1990; 14:174

H D C Roscam Abbing

- Privacybescherming, medische (persoons-)gegevens en wetenschappelijk onderzoek. RL vakgroep gezondheidsrecht, december 1988

- Medische (persoons)gegevens, lichaamsmateriaal en wetenschappelijk onderzoek. TIjdschr Gezondheidsr 1989; 13:362

- Wetenschappelijk onderzoek, medische persoonsgegevens en privacybescherming. Privacy en registratle 1992; $17: 11$

C Spreeuwenberg

- Staan patiëntenwetten de gezondheld In de weg? Medisch Contact 1991; 46:1019

- Een gedragscode voor gezondheidsonderzoek. Medlsch Contact 1992; 47:515

$J P$ Vandenbroucke

- Medische ethiek en gezondheldsrecht; hinderpalen voor de verdere toename van kennis in de geneeskunde? Ned Tljdschr Geneesk 1990; 134:5

- Wetenschappelijk onderzoek en prlvacy; het belang van zorgvuldige afweging. Ned Tijdschr Geneesk 1991; 135:1023 + 1099

- Gaat de patiëntenwet stranden op de praktijk? Een Spokeplas-zlekte? Medisch Contact 1991; 46:1083

Doctoraalscripties

M Ni|ssen

- Prlvacy versus medische registratie (rechtsgeieerdheid RUL, november 1990)

I A van Asperen

- Het gebruik van lichaamsmateriaal voor bijzondere doeleinden: een literatuuronderzoek en een discussie-overzicht (blomedische wetenschappen RUL, maart 1992) 